\title{
Effect of sediment particle size on recruitment of Owenia fusiformis in the Bay of Blanes (NW Mediterranean Sea): an experimental approach to explain field distribution
}

\author{
S. Pinedo ${ }^{1, *}$, R. Sardá ${ }^{1}$, C. Rey $^{2}$, M. Bhaud ${ }^{3}$ \\ ${ }^{1}$ Centre d'Estudis Avançats de Blanes, Camí Sta. Bàrbara s/n, 17300 Blanes, Girona, Spain \\ ${ }^{2}$ Station Zoologique, URA 716, BP 28, 06230 Villefrance-sur-mer, France \\ ${ }^{3}$ Observatoire Océanologique CNRS, Laboratoire Arago, 66650 Banyuls-sur-mer, France
}

\begin{abstract}
The spatial distribution of the tubicolous polychaete Owenia fusiformis Delle Chiaje in the Bay of Blanes was studied during summer 1996. Populations were located on sandy sediments and a heterogeneous distribution of specimens was found. Three areas with different densities were observed: the vicinity of the harbour, the mouth of the Tordera River, and the open bay. Although adult individuals were present all over the bay at low densities, large numbers were mainly found near the harbour. Differences in mean individual biomass were also observed among stations. The largest individuals were found at the mouth of the river, where the fluxes of suspended matter were maximal. Juveniles of $O$. fusiformis also showed a regular pattern of spatial variation along the bay. The highest density of juveniles was found in the area where high densities of adults occurred. The consequences of this spatial variability were analyzed in relation to the effect of sediment grain size on 3 successive processes of recruitment (metamorphosis, juvenile transformation and tube construction) in running still-water experiments. The influence of sediment particle size on the disappearance of larvae in the 3 processes was analyzed. The large grain size of the substratum had a significant negative effect on the construction of $O$. fusiformis tubes. After settlement, $O$. fusiformis needs a high percentage of fine sediment to construct the tube. Our results support the hypothesis that the spatial distribution pattern of the species in the field is influenced by sediment particle size. The importance of the presence of $O$. fusiformis adult tubes and seagrass shoots in stabilizing the sediments, and thus determining the pattern, is also discussed.
\end{abstract}

KEY WORDS: Owenia fusiformis $\cdot$ Recruitment $\cdot$ NW Mediterranean $\cdot$ Population structure $\cdot$ Spatial variability

Resale or republication not permitted without written consent of the publisher

\section{INTRODUCTION}

The polychaete Owenia fusiformis Delle Chiaje is a polythelic species with a bentho-pelagic cycle. $O$. fusiformis is characterized by a short reproductive period in spring with a pelagic larval life of approximately 1 mo (Wilson 1932, Thiébaut et al. 1992, S.P. \& R.S. unpubl.). Records of this species refer to different types of soft-bottom locations. In the Mediterranean

*E-mail: pinedo@ceab.csic.es
Sea, the species has been recorded at the mouth of many rivers (Cognetti-Varriale \& Zunarelli-Vandini 1979, Gambi \& Giangrande 1986, Ambrogi et al. 1990). Although Pérès \& Picard (1964) reported O. fusiformis as being characteristic of communities of terrigenous mudshelves, this species is frequently associated with subtidal sandy sediments (Picard 1965, ZunarelliVandini \& Cognetti-Varriale 1978, Gambi \& Giangrande 1986, Ambrogi et al. 1990). The distribution of $O$. fusiformis in the Tyrrhenian Sea, for example, appeared to be related to the proportion of silt and clay fractions (Somaschini 1993). 
Owenia fusiformis is one of the most common species in the fine to coarse-sand benthic communities of the Bay of Blanes (NW Mediterranean Sea). O. fusiformis density in the bay rises sharply during spring (recruitment period: April-June, Pinedo et al. 1996, S.P. \& R.S. unpubl.), followed by a dramatic drop throughout the summer (high mortality), and remains low during autumn and winter. Every year, different recruit densities were observed at the 3 stations studied in the bay (S.P. \& R.S. unpubl.). The sedimentological characteristics of each station could determine the differences in spatial recruitment observed. No studies have been found in relation to the direct influence of the substratum particle size in the recruitment of this species.

The influence of bottom sediment upon the settlement of marine benthic species was first noticed by Mortensen (1921) in echinoid larvae. Since then, numerous benthic studies have shown that the species distribution of soft-sediment infaunal invertebrates usually correlates closely with the distribution of particular sediment types (Scheltema 1974, Butman 1987,

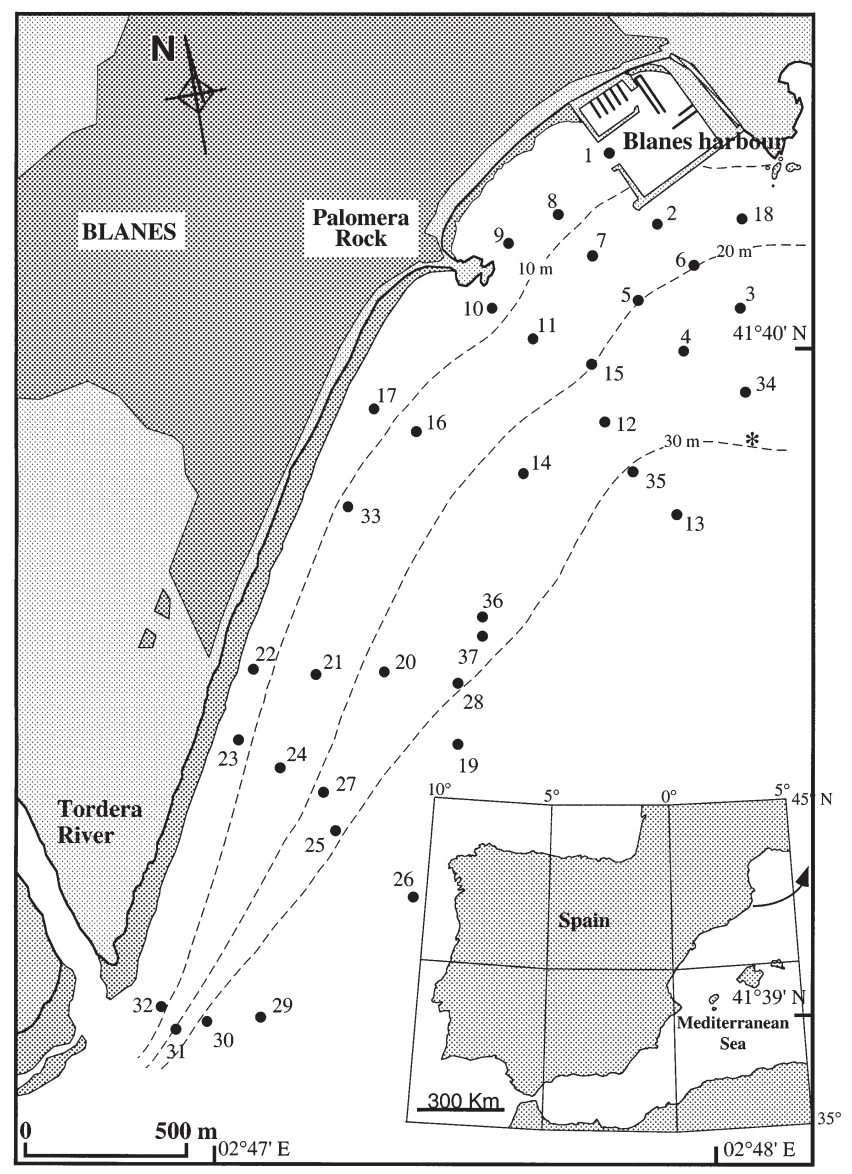

Fig. 1. Location of benthic stations in the Bay of Blanes (NW Mediterranean Sea). (*) Position of the sewage outlet
James \& Underwood 1994, Snelgrove \& Butman 1994). Wilson reported the importance of substratum size and form on the metamorphosis of the ophelidae larvae $(1948,1952,1953 a, b, 1955)$ and the metamorphosis delay in the absence of substratum for the Owenia fusiformis larvae (1932). Recruitment, defined as metamorphosis, settlement (juvenile transformation and tube construction) and survival (Underwood 1979), involves a combination of physical and biological factors which are responsible for the spatial distribution of populations (James \& Underwood 1994).

The mitraria larvae of Owenia fusiformis pass through different stages in the water column until metamorphosis is complete in the substratum (see Wilson 1932 to review the larval stages). Within a few hours after metamorphosis, a young worm in a mucous tube with irregularly attached sand grains can be observed. As the worm grows, new particles are attached to the tube's lower portion and the tube is built upwards. Given these conditions, we tested the hypothesis that sediment particle size influences recruitment controlling some early stage(s) of the life cycle of O. fusiformis.

This paper describes the spatial distribution, density and population structure of the summer macrobenthic population of Owenia fusiformis in the Bay of Blanes (NW Mediterranean Sea). In order to determine the influence of sediment particle size on this distribution, we present the results of still-water laboratory experiments designed to examine how substratum particle size, per se, affects recruitment. Few studies offer such experimental evidence explaining the spatial distribution of species observed in the field as we show in this paper.

\section{MATERIAL AND METHODS}

Field distribution. The distribution of Owenia fusiformis was established by sampling at 37 stations between Blanes harbour and the mouth of the Tordera River (Fig. 1). Samples were obtained in July 1996 using a van Veen grab of $600 \mathrm{~cm}^{2}$ area. They were then sieved through a $1 \mathrm{~mm}$ screen, and preserved in a $10 \%$ formalin seawater solution stained with Rose Bengal. In addition, some samples were filtered by 0.5 and $1 \mathrm{~mm}$ screens (Stns 1, 7, 15, 20, 31) to determine the loss of small individuals. The percentage of juveniles lost when using a $1 \mathrm{~mm}$ screen was 4 and $9 \%$ at Stns 1 and 7, respectively: no loss was observed at the other stations. Such proportions were insignificant for the purpose of this study.

The organisms retained by the sieve were counted. The maximum width of the tube $\left(W_{\mathrm{t}}\right)$ was measured for all specimens of Owenia fusiformis and individuals 
were separated into 13 size classes based on this measurement. A binocular microscope equipped with a camera lucida and digitizing tablet (Houston Instruments HiPad) linked to a computer was used for all measurements. The relationship between tube width and the length of the fourth abdominal segment $\left(I_{4}\right)$ was $I_{4}(\mu \mathrm{m})=-160.6940+1.8973 W_{\mathrm{t}}(\mu \mathrm{m})\left(\mathrm{r}^{2}=0.75, \mathrm{n}=\right.$ 77, $\mathrm{p}<0.05)$. Regression between $I_{4}(\mu \mathrm{m})$ and biomass $(\mathrm{mg})\left(W=0.33 \times I_{4}{ }^{1.844}, \mathrm{r}^{2}=0.81, \mathrm{n}=107, \mathrm{p}<0.05\right)$ was used to convert measured lengths to weight. Observations of the reproductive biology of $O$. fusiformis in the Bay of Blanes (S.P. \& R.S. unpubl.) showed that adult individuals were $>1.4 \mathrm{~mm} I_{4}$, and juveniles $<1.1 \mathrm{~mm} I_{4}$. The individuals that comprised between 1.1 and $1.4 \mathrm{~mm} I_{4}$ were classified as being at an indeterminate stage. These measures corresponded with individuals $\geq 0.8 \mathrm{~mm} W_{\mathrm{t}}$ as adults and those $\leq 0.7 \mathrm{~mm} W_{\mathrm{t}}$ as juveniles.

Sediment subsamples were collected from the grab for organic matter content and granulometric analysis. Organic content of dry sediment was estimated as the loss of weight after ashing. Granulometric analysis was conducted with a Coulter® LS Particle Size Analyzer at the Department of Dynamic Geology, University of Barcelona. The classification of sediments followed Wentworth's scale (1972): silt-clay $(<63 \mu \mathrm{m})$, very fine sand (63 to $120 \mu \mathrm{m})$, fine sand (120 to $250 \mu \mathrm{m})$, medium sand (250 to $500 \mu \mathrm{m})$, coarse sand (500 to $750 \mu \mathrm{m})$, and very coarse sand (750 to $1000 \mu \mathrm{m})$.

Experimental design. The still-water laboratory experiments designed to determine how substratum particle size affects recruitment of Owenia fusiformis were conducted at the Laboratoire Arago (Banyuls-sur-mer). O. fusiformis larvae were collected in the Bay of Banyuls (French Catalan coast, NW Mediterranean Sea) with a $200 \mu \mathrm{m}$ mesh net. Larvae were separated and maintained at low densities in dishes with $0.2 \mu \mathrm{m}$ filtered seawater. Cultured Dunaliella tertiolecta were supplied daily as food for larvae. All experiments were carried out at $13^{\circ} \mathrm{C}$, a temperature similar to that in the seawater in the bay during the experimental period. Wilson's descriptions (1932) were used to classify the organisms (larvae, postlarvae and juveniles) according to the different morphological stages during the experiment.

To assess the effect of sediment size on recruitment, 4 to 7 replicates of each substratum (treatment) were tested in circular dishes $5.5 \mathrm{~cm}$ in diameter and $3 \mathrm{~cm}$ deep. Recruitment was considered successful when each of 3 phases (larval metamorphosis, postlarvae becoming juveniles and the construction of the tubes) was complete. To each dish, 3 individuals (larvae, postlarvae, or juveniles, depending on the experiment), together with sediment and filtered seawater, were added. Sediment from the known Spisula subtruncata community, the natural habitat of the Owenia fusiformis population, was used. This sediment is characterized by its heterogeneous grain size and regular form. Six different grain sizes $(\mu \mathrm{m})$ were tested separately in the experiments: <63, 80-125, 125-160, 160-200, 200-250 and 250-500. The sediments did not contain organic matter, as it was eliminated after ashing $\left(5 \mathrm{~h}\right.$ at $\left.450^{\circ} \mathrm{C}\right)$. Every $2 \mathrm{~d}$, seawater was changed with a pipette and 4 drops of fresh food supplied, and the developmental stage of individuals was recorded under a binocular microscope.

At the end of the observations a number of individuals introduced at the beginning of the experiments were missing. The relationship between organism disappearance (either by manipulation of the experiments or mortality) and sediment particle size was analyzed before testing the success on the 3 experimental phases (metamorphosis, juvenile transformation, and tube construction).

Statistical treatment. Pearson regression analysis was used to analyze the relationships between the environmental parameters (sedimentological variables: $\%$ silt-clay, $\%$ fine material $<120 \mu \mathrm{m}$, and mean sediment size; organic matter content; and water depth) and biological variables (density of Owenia fusiformis, adult and juvenile densities [relative and absolute values] total biomass, and individual biomass).

Data were checked for normality and homogeneity of variances (as tested by Kolmogorov-Smirnov and Bartlett tests, respectively) in each experiment. When the assumptions were not met, non-parametric analyses were used. The analysis of variance (parametric 1-way ANOVA and Kruskal-Wallis test) was used to test the effect of grain size. Tukey's HSD multiple-comparisons tests were performed to determine which sediment sizes were different when the effect was statistically significant at $\mathrm{p} \leq 0.05$ in the ANOVA models. Pearson regression analysis was used to analyze the relationships between success in each phases and sediment grain size.

\section{RESULTS}

\section{Field distribution}

The classification of the sediments throughout the Bay of Blanes is illustrated in Fig. 2. The eastern part of the Bay of Blanes contains fine sediments and the bed is partly covered with the seagrass Cymodocea nodosa from the Palomera Rock to its eastern limit.

The highest densities of total Owenia fusiformis (3400 to 10585 ind. $\mathrm{m}^{-2}$ ) were found in the eastern part of the bay, in the vicinity of the Blanes harbour, which is characterized by fine sand sediments. Population 


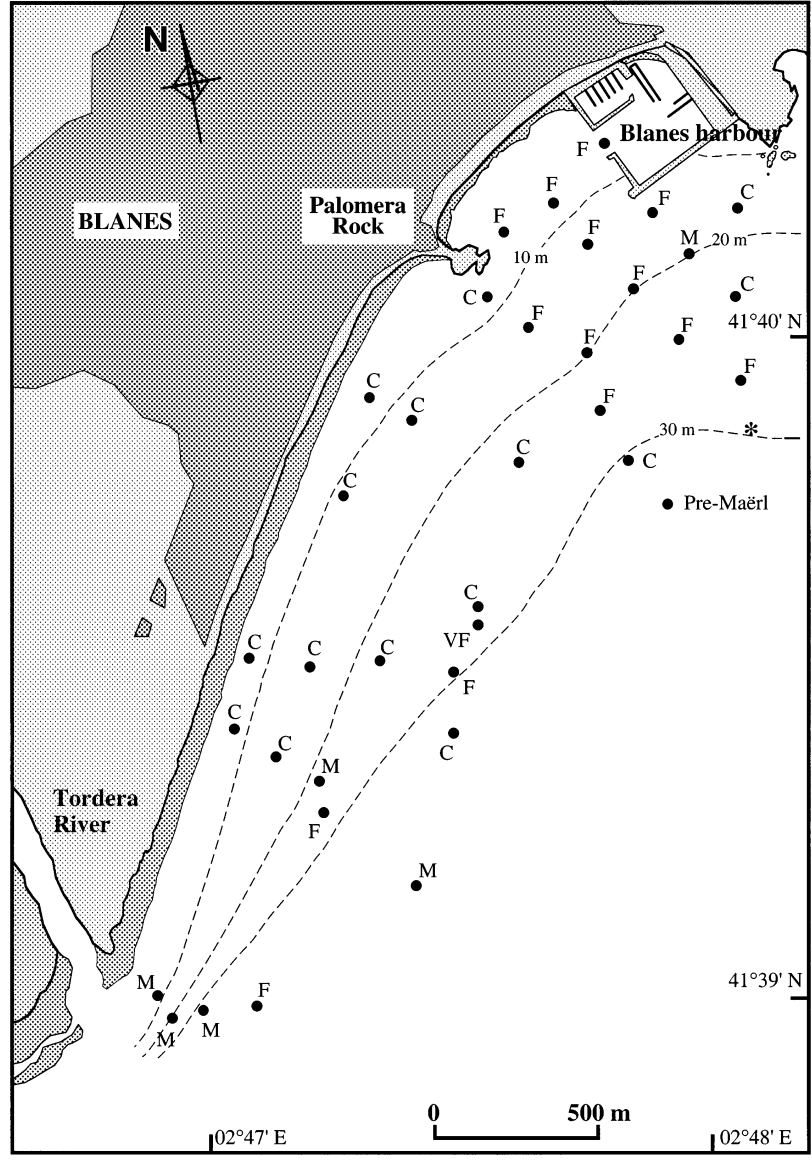

Fig. 2. Sediment classification of benthic stations in the Bay of Blanes (NW Mediterranean Sea). VF: very fine sand sediment; F: fine sand sediment; $\mathrm{M}$ : medium sand sediment; $\mathrm{C}$ : coarse sand sediment (following the classification of Wentworth 1972: silt-clay [<63 $\mu \mathrm{m}$ ], very fine sand [63 to $120 \mu \mathrm{m}$ ], fine sand [120 to $250 \mu \mathrm{m}$ ], medium sand [250 to $500 \mu \mathrm{m}$ ], coarse sand [500 to $750 \mu \mathrm{m}$ ], and very coarse sand [750 to $1000 \mu \mathrm{m}])$

densities were lower (117 to 267 ind. $\mathrm{m}^{-2}$ ) in the area close to the mouth of Tordera River, characterized by medium to fine sand sediments. Densities fell to between 17 and 83 ind. $\mathrm{m}^{-2}$ in the rest of the bay (Fig. 3).

The pattern was the same for adult organisms. Thus, in the area near the harbour, from 2000 to 5468 ind. $\mathrm{m}^{-2}$ were registered. Densities did not exceed 150 ind. $\mathrm{m}^{-2}$ in the rest of the bay (Fig. 4). Although the highest densities of adults were located near the harbour, the biggest individuals $(>2 \mathrm{mg}$ ind. ${ }^{-1}$ ) were found at the mouth of the river. Juvenile distribution also varied spatially (Fig. 5). Highest densities were observed in the area near the harbour (1400 to 7468 ind. $\mathrm{m}^{-2}$ ), where the main adult population was located. Densities ranged from 17 to 533 ind. $\mathrm{m}^{-2}$ in the rest of bay.

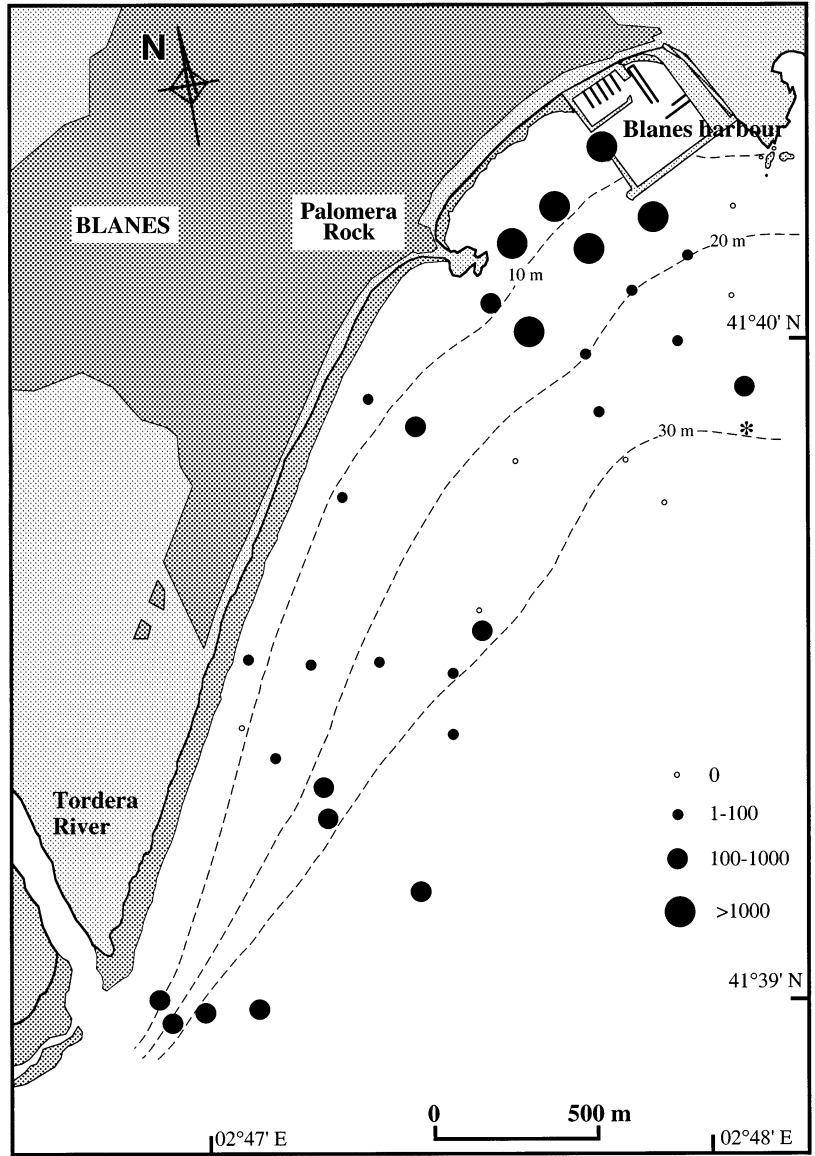

Fig. 3. Owenia fusiformis. Distribution and densities (ind. $\mathrm{m}^{-2}$ ) of the polychaete population in July 1996

\section{Correlations between variables}

As expected, the organic matter content of sediments was related to the sedimentological variables: the percentage of silt-clay $(r=0.6657, \mathrm{p}<0.001)$, the percentage of fine sand material $(r=0.7732, p<0.001)$, and the mean sediment size $(r=-0.8431, p<0.001)$. The relationships between the environmental variables and the distribution of Owenia fusiformis are summarized in Table 1.

Total density and density of juveniles (absolute and percentage values) were the biological variables most correlated with environmental parameters. Individual biomass and adult percentages in the bay did not correlate with any of the variables considered. Depth showed a negative relationship with Owenia fusiformis distribution for the total density and biomass and adult and juveniles densities. The mean sediment size and the content of sediment material $<120 \mu \mathrm{m}$ were the main sedimentological variables explaining the field distribution of $O$. fusiformis in the bay. The 


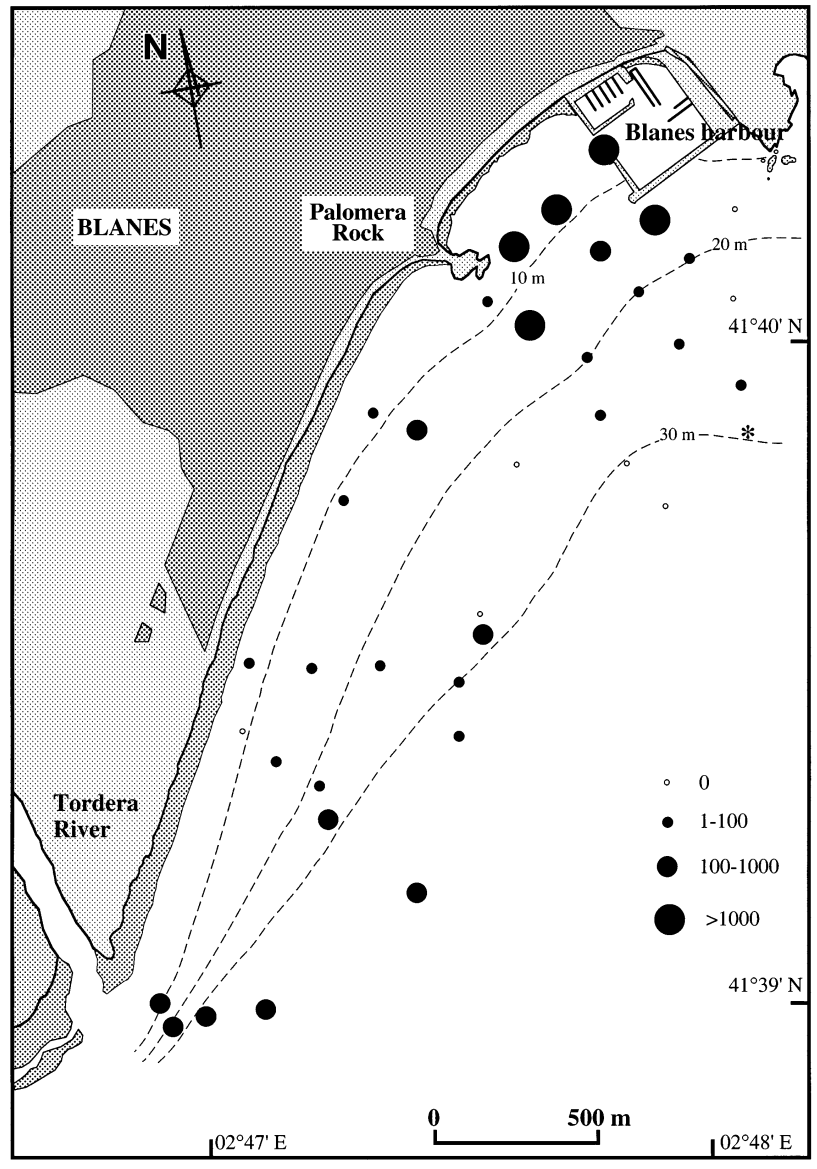

Fig. 4. Owenia fusiformis. Adult distribution and densities (ind. $\mathrm{m}^{-2}$ ) of the polychaete population in July 1996

percentage of silt-clay only affected the distribution of juveniles (in percentage).

\section{Experimental results}

Sediment size was not a significant factor $(p>0.05)$ in the disappearance of organisms in the 3 experiments (Table 2). Thus, data from the different particle sizes were pooled to observe the effect of substratum on the

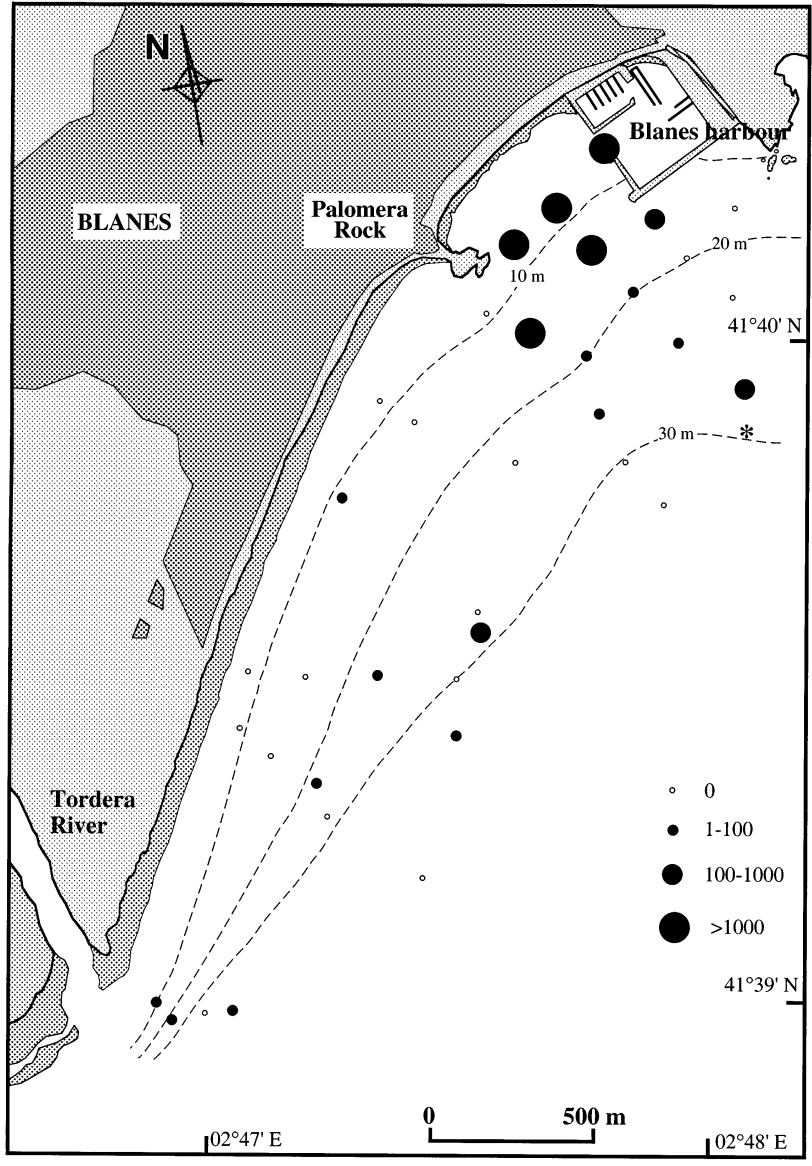

Fig. 5. Owenia fusiformis. Juvenile distribution and densities (ind. $\mathrm{m}^{-2}$ ) of the polychaete population in July 1996

disappearance during the 3 phases of the recruitment process (Fig. 6). Neither manipulation nor larval mortality were greater than $14 \%$.

Sediment size treatment did not significantly affect the metamorphosis and juvenile transformation phases (Table 3). When pooling data, the percentage of metamorphosed larvae was higher than $60 \%$, and nearly $90 \%$ of postlarvae became juvenile worms (Fig. 7). However, significant differences were revealed by the 1-way ANOVA for the effect of grain size of the Spisula

Table 1. Pearson regression analysis (r) between environmental variables and Owenia fusiformis distribution in the Bay of Blanes $\left({ }^{*} \mathrm{p}<0.05,{ }^{* *} \mathrm{p}<0.01,{ }^{* * *} \mathrm{p}<0.001,-\right.$ : no significant relationships; $\mathrm{n}=36$ for all cases)

\begin{tabular}{|c|c|c|c|c|c|c|c|}
\hline & Total density & Total biomass & Biomass/Density & Adults (n) & Adults (\%) & Juveniles (n) & Juveniles (\%) \\
\hline Mean sediment size $(\mu \mathrm{m})$ & $-0.4203^{* *}$ & - & - & - & - & $-0.4276^{* *}$ & $-0.6656^{* * *}$ \\
\hline$<63 \mu \mathrm{m}(\%)$ & - & - & - & - & - & - & $0.3328^{*}$ \\
\hline$<120 \mu \mathrm{m}(\%)$ & $0.3599^{*}$ & - & - & - & - & $0.4127^{*}$ & $0.6805^{* * *}$ \\
\hline Organic matter (\%) & - & $0.3337^{*}$ & - & - & - & - & $0.5039^{* *}$ \\
\hline Depth (m) & $-0.4328^{* *}$ & $-0.3867^{*}$ & - & $-0.3882^{*}$ & - & $-0.3660^{*}$ & - \\
\hline
\end{tabular}


Table 2. 1-way ANOVA (parametric, F-value and non-parametric, Kruskal-Wallis [K-W] statistic). Organism disappearance as a result of sediment size as a factor

\begin{tabular}{|lcccc|}
\hline Treatment & F-value & K-W statistic & df & $\mathrm{p}$ \\
\hline Metamorphosis & 0.3569 & - & 5 & 0.8729 \\
Juvenile transformation & - & 2.7852 & 5 & 0.7331 \\
Tube construction & - & 10.9699 & 5 & 0.0520 \\
& & & & \\
\hline
\end{tabular}

Table 3. 1-way ANOVA (parametric, F-value and non-parametric, Kruskal-Wallis [K-W] statistic). Success on the 3 different phases with sediment size as a factor

\begin{tabular}{|lccccc|}
\hline Treatment & F-value & K-W statistic & df & $\mathrm{p}$ \\
\hline Metamorphosis & 0.4210 & - & 5 & 0.8296 \\
Juvenile transformation & - & 4.3463 & 5 & 0.5007 \\
Tube construction & 4.7390 & - & 5 & 0.0014 \\
\hline
\end{tabular}

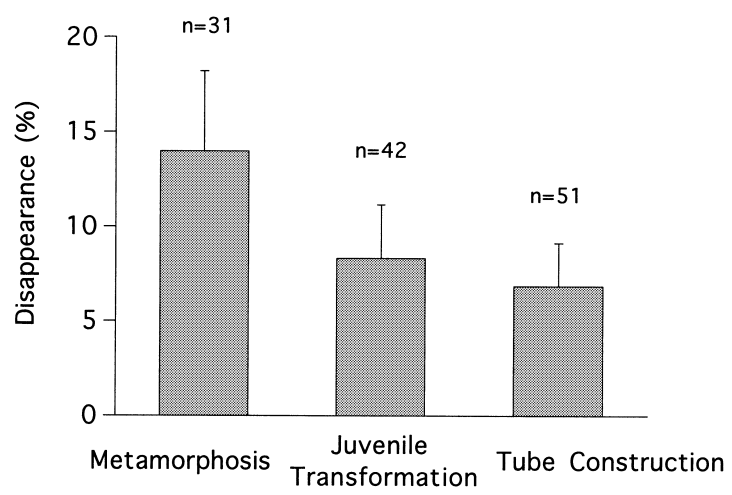

Fig. 6. Mean disappearance of organisms in the 3 phases analyzed. The number of organisms tested is indicated at the top of each bar. Error bars indicate standard errors

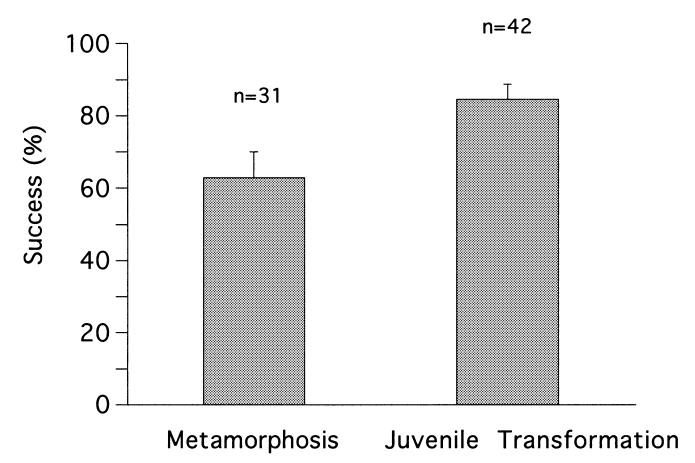

Fig. 7. Successful metamorphosis and juvenile transformation. The number of organisms tested is indicated at the top of each bar. Error bars indicate standard errors

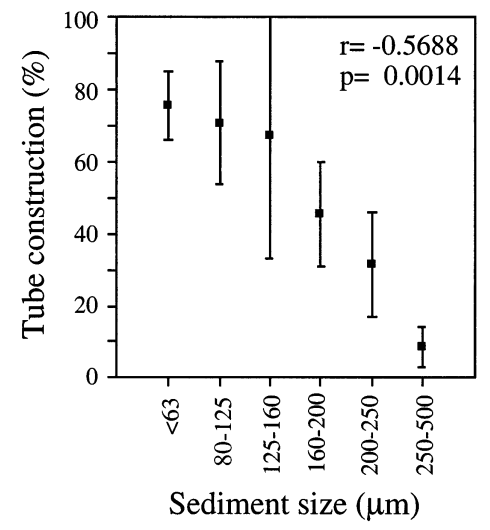

Fig. 8. Organisms with sand tubes as a function of grain size. Error bars indicate standard errors

subtruncata sediment on the tube construction phase (Table 3). The success of tube construction and the $S$. subtruncata sediment size were negatively correlated (Fig. $8 ; \mathrm{r}=-0.57, \mathrm{p}<0.001$ ). More than $70 \%$ of organisms were able to construct tubes with very fine sand sediments. As the sediment size increased the rate of success was significantly lower.

\section{DISCUSSION}

The fine fractions of the sediments seem to play an important role in structuring Owenia fusiformis population in the Bay of Blanes. Although successful recruitment of $O$. fusiformis was observed throughout the bay, the highest densities were found in the harbour area and in the area just in front of the Tordera River. Both sites receive large quantities of fine suspended material, either from the small creek located in the village of Blanes or from freshwater pulses from the Tordera River. This pattern coincides with the patchy distribution described by Dauvin \& Gillet in the Bay of Seine (Dauvin \& Gillet 1991, Dauvin 1992). They found patches of high densities associated with sediment size (the percentage of particles $<63 \mu \mathrm{m}$ should be $>4 \%$ ). The very low density of individuals in certain communities was attributed to the low proportion of fine particles. They also observed a rapid disappearance of $O$. fusiformis juveniles following recruitment where very fine particles were $<5 \%$. Here, the 2 high-density patches of $O$. fusiformis juveniles at Stns 34 and 37 in the Bay of Blanes (88 and $78 \%$ of the total density of $O$. fusiformis, respectively) might be explained by the high percentage of silt-clay (close to $11 \%$ ) compared with that of nearby stations. Stn 34 is influenced by the presence of the outlet of a pipeline which also discharges fine material, while Stn 37 is in an area of very fine sediment surrounded by coarse sand sediments (Fig. 2). 
Our experimental results indicate that tube building success is strongly dependent on grain size and it could explain the distribution observed in the Bay of Blanes. The tube construction phase, influenced by substratum characteristics, could be responsible for the successful recruitment of this species in the bay. When the percentage of fine fraction sediment is low, the construction of tubes by juveniles could be greatly reduced. Consequently, new recruits dispersed over these areas may not survive. The concept of an optimum sediment particle size on settlement has previously been proposed by Wilson (1952) for Ophelia bicornis larvae. The Bay of Blanes showed a great variation in its sediment composition. The fine sediment $(\leq 120 \mu \mathrm{m})$ content ranged from 1 to $57 \%$. When examining the finest fraction $(<63 \mu \mathrm{m})$, the proportions ranged from 0.7 to $14.8 \%$. The difference in recruitment between fine-coarse sediment habitats corroborates our laboratory findings. Our experimental results demonstrate that larvae can settle and metamorphose in different sediments with a high success rate of juvenile transformation, though this is independent of the viability of future tube construction. The high rate $(75 \%)$ of tube construction success with the finer fractions demonstrates that the granulometric composition of the substratum can have a strong influence on the viability of settlement. Our results corroborate Wilson's observations that the substratum affects the life cycle of Owenia fusiformis.

Fager (1964) reported further evidence of the importance of sediment particle size and form in Owenia fusiformis recruitment by the microscopic examination of the tubes of young worms. He showed that the tubes were composed almost entirely (95\% or more) of tabular shaped, heavy mineral grains ranging in size from 62 to $80 \mu \mathrm{m}$. Similarly, Toulemont (1972) found the highest densities of the worm in an area with a high percentage of 60 to $180 \mu \mathrm{m}$ material and noted that $O$. fusiformis constructed the tube with more than $50 \%$ fine particles and with less than $5 \%$ of silt-clay. At the mouth of the Tordera River, the medium sand stations only contain as little as 5 to $7 \%$ fine material $(<120 \mu \mathrm{m})$, so the worms need to sort the material rigorously. However, this percentage seems to be sufficient for $O$. fusiformis to settle and colonize the area and to form a population of adult worms. Fager emphasized the importance of a combination of size and shape. Personal observations of the construction of the tube with different morphological sediments (natural sediment of Spisula subtruncata community and artificial sediment of Fointainebleau) seem to agree with Fager's observations. Worms were unable to construct a functional tube with irregular and obtuse angle particles such as those found in the Fointainebleau sediment.
After successful recruitment, food availability seems to play an important role in the distribution of the organisms. Fluxes of suspended material control the density of Owenia fusiformis as in the case with other suspension-feeders (Snelgrove \& Butman 1994). O. fusiformis has the advantage of being able to adjust its feeding behaviour so as to feed on suspension or deposited material on the bottom (McCall 1977, Taghon et al. 1980, Gambi 1989). In the Bay of Blanes the largest individuals were found at the mouth of the river, where the suspended material is most abundant. As has been observed in the Bay of Seine (Dauvin 1992), O. fusiformis recruits to areas with high fluxes of suspended matter such as those just seaward of the Tordera River in the Mediterranean Sea. We also noted that high densities were recorded near the sewage outlet in the Bay of Blanes. On the other hand, higher growth could be also related to lower intra-specific competition (lower densities) as it occurred in the mouth of the Tordera River. At any rate, based on the correlation between organic matter and species distribution showed in Table 1, one can speculate about the relationship between larval settlement and organic matter since high organic matter content may enhance higher larval settlement, higher juvenile survival (more food availability) and juvenile growth rate, and then higher population density. Future experiments should consider the importance of organic matter in terms of affecting organism recruitment.

Rey (1995) determined the capacity of the ascending movement of Owenia fusiformis larvae in seawater as $0.7 \mathrm{~mm} \mathrm{~s}^{-1}$. This velocity, as a result of ascending power and gravitation, is very low when compared with that estimated for other polychaetes (cf. Mileikovsky 1973), and is within the range of gravitational fall velocities estimated for old planktonic larvae (Hannan 1984). Experimental evidence supports the passive deposition hypothesis as the operating mechanism during $O$. fusiformis larval settlement. Passive deposition of larvae related to hydrodynamics contributes to patterns of colonization (Fager 1964, Jumars \& Nowell 1984). The correspondence between distributional patterns of benthic organisms with fine sediment distributions has been attributed to the passive accumulation of settling larvae and sediments in areas that are sheltered or have weak currents and depressions on the sea floor (Verwey 1952, Kristensen 1957, Carriker 1961, Fager 1964, Scheltema 1974, Levin 1984, Butman 1987). Moreover, the stability can be also attributed to the presence of tubicolous organisms (Woodin 1978, Eckman 1979, 1983, Atkins 1983, Hsieh \& Chang 1991), or that of seagrass beds (Virnstein et al. 1983, Peterson et al. 1984, Thistle et al. 1984). Nowell \& Church (1979) showed that the density of $O$. fusiformis tubes required to stabilize the sediment must be 
around 14500 ind. $\mathrm{m}^{-2}$ (considering individuals of $2.7 \mathrm{~mm}$ tube diameter). However, Fager (1964) observed stable sediments where $O$. fusiformis density was 500 to 1000 ind. ${ }^{-2}$. Eckman (1985) and Eckman et al. (1981) showed that mucous production by enhanced bacterial growth around tubes could stabilize sediments at any field density encountered. Thus, the density values of $O$. fusiformis adult populations found in the Bay of Blanes could be relevant in considering larval settlement. On the other hand, bacterial growth could also serve as chemical cues for larval settlement as well as the food source of newly settled juvenile, which could also lead to a higher recruitment rate.

Levin (1982) suggested adult-larva interactions may be involved in the regulation of settlement. Unlike other polychaetes (Levin 1982, 1984, Wilson 1983, 1984, Zajac 1986, Bhaud 1991) and unlike Owenia fusiformis post-larval settlement in the Bay of Seine (Dauvin 1992), in the Bay of Blanes the recruitment of juveniles was higher where adult densities were highest. Desroy (1994) proved that adult $O$. fusiformis enhanced the settlement of Pectinaria koreni larvae and this could be the mechanism enhancing $O$. fusiformis larvae in the Bay of Blanes. On the other hand, higher recruitment was also observed at the stations where sediments are stabilized by the presence of the seagrass Cymodocea nodosa (the area around Stns 7 and 9). Therefore, adult tubes and seagrass could affect the spatial distribution of $O$. fusiformis observed in the Bay of Blanes.

In summary, physical processes and biological interactions could determine the spatial distribution of the Owenia fusiformis population. Passive dispersion and deposition drive the settlement pattern, though the larvae are able to settle in a wide range of substrata. After settlement, young worms need a high percentage of the fine fraction $(<120 \mu \mathrm{m})$ of sediment to construct tubes and to grow. This might constitute a limiting factor for a viable recruitment. The presence of adult tubes or seagrass shoots, stabilizing the sediment, could also facilitate recruitment and the posterior viability of recruits.

Acknowledgements. This research was supported by the project CICYT AMB94-0746, by a predoctoral fellowship from the Education and Science Office and a research contract from the CSIC to S.P. We wish to thank G. Carreras, S. Herrera, M. Puig and S. Taboada for their help during the sampling and procedure. We thank Daniel Martin and Tim Granata for stimulating and critical comments.

\section{LITERATURE CITED}

Ambrogi R, Bedulli D, Zurlini G (1990) Spatial and temporal patterns in structure of macrobenthic assemblages. A three-year study in the Northern Adriatic Sea in front of the Po River Delta. PSZN I Mar Ecol 11:25-41
Atkins SM (1983) Contrast in benthic community structure of North Yorkshire coast. In: Boutler J (ed) Fluctuation and succession in marine ecosystems. Oceanol Acta, Proc 17th Eur Mar Biol Symp, Brest, France, p 7-10

Bhaud M (1991) Larval release from the egg mass and settlement of Eupolymnia nebulosa (Polychaeta, Terebellidae). Bull Mar Sci 48:420-431

Butman CA (1987) Larval settlement of soft-sediment invertebrates: the spatial scales of pattern explained by active habitat selection and the emerging role of hydrodinamical processes. Oceanogr Mar Biol Annu Rev 25:113-165

Carriker MR (1961) Interrelation of functional morphology, behavior, and autoecology in early stages of the bivalve Mercenaria mercenaria. J Elisha Mitchell Sci Soc 77: $168-241$

Cognetti-Varriale AM, Zunarelli-Vandini R (1979) Polychaetes of littoral sandy bottoms along the North Latium coast. Boll Zool 46:77-86

Dauvin JC (1992) Cinétique du recrutement et croissance des juvéniles d'Owenia fusiformis Delle Chiaje en baie de Seine (Manche orientale). Oceanol Acta 15:187-196

Dauvin JC, Gillet P (1991) Spatio-temporal variability in population structure of Owenia fusiformis Delle Chiaje (Annelida: Polychaeta) from the Bay of Seine (eastern English Channel). J Exp Mar Biol Ecol 152:105-122

Desroy N (1994) Roles des interactions adultes-recrues dans la structuration des populations d'invertebres benthiques en régime mégatidal. Cas de Pectinaria koreni (Malmgren) et Owenia fusiformis Delle Chiaje (Annélides Polychètes). DEA Biologie des populations et éco-éthologie. Museum National D'Histoire Naturelle, Dinard

Eckman JE (1979) Small-scale patterns and processes in a softsubstratum intertidal community. J Mar Res 37:437-457

Eckman JE (1983) Hydrodynamic processes affecting benthic recruitment. Limnol Oceanogr 28:241-257

Eckman JE (1985) Flow disruption by an animal-tube mimic affects sediment bacterial colonization. J Mar Res 43: 419-435

Eckman JE, Nowell ARM, Jumars PA (1981) Sediment destabilization by animal tubes. J Mar Res 39:361-374

Fager EW (1964) Marine sediments: effects of a tube-building polychaete. Science 143:356-359

Gambi MC (1989) Osservazioni su morfologia funzionale e comportamento trofico di Owenia fusiformis Delle Chiaje (Polychaeta, Oweniidae) in rapporto ai fattori ambientali. Oebalia XV-1:145-155

Gambi MC, Giangrande A (1986) Distribution of soft-bottom polychaetes in two coastal areas of the Thyrrenian Sea (Italy): structural analysis. Estuar Coast Shelf Sci 23: 847-862

Hannan CA (1984) Planktonic larvae may act like passive particles in turbulent near-bottom flows. Limnol Oceanogr 29: 1108-1116

Hsieh HL, Chang KH (1991) Habitat characteristics and occurrence of the spionid Pseudopolydora sp. on the tubecaps of the onuphid Diopatra bilobata (Polychaeta: Spionidae, Onuphidae). Bull Inst Zool 30:331-339

James RJ, Underwood AJ (1994) Influence of colour of substratum on recruitment of spirorbid tubeworms to different types of intertidal boulders. J Exp Mar Biol Ecol 181: 105-115

Jumars PA, Nowell ARM (1984) Effects of benthos on sediment transport: difficulties with functional grouping. Cont Shelf Res 3:115-130

Kristensen I (1957) Differences in density and growth in a cockle population in the Dutch Wadden Sea. Arch Néerl Zool 12:351-453 
Levin L (1982) Interference interactions among tube-dwelling polychaetes in a dense assemblage. J Exp Mar Biol Ecol 65:107-119

Levin L (1984) Life-history and dispersal patterns in a dense infaunal polychaete assemblage: community structure and response to disturbance. Ecology 65:1185-1200

McCall PL (1977) Community patterns and adaptive strategies of the infaunal benthos of Long Island Sound. J Mar Sci 35:221-266

Mileikovsky SA (1973) Speed of active movement of pelagic larvae of marine bottom invertebrates and their ability to regulate their vertical position. Mar Biol 23:11-17

Mortensen T (1921) Studies of the development and larval forms of echinoderms. Copenhagen G E C Gad, Copenhagen

Nowell AR, Church M (1979) Turbulent flow in a depthlimited boundary layer. J Geophys Res 84:4816-4824

Pérès JM, Picard J (1964) Nouveau manuel de bionomie bentique de la Mer Méditerranée. Recl Trav Stn Mar Endoume 31:5-137

Peterson CH, Summerson HC, Duncan PB (1984) The influence of seagrass cover on population structure and individual growth rate of a suspension-feeding bivalve, Mercenaria mercenaria. J Mar Res 42:123-138

Picard J (1965) Rechèrches qualitatives sur les biocoenoses marines de substrats meubles dragables de la région marseillaise. Recl Trav Stn Mar Endoume 36:1-160

Pinedo S, Sardá R, Martin D (1996) Seasonal dynamics and structure of soft-bottom assemblages in Blanes Bay (northwest Mediterranean Sea). Publ Espec Inst Oceanogr 22: $61-70$

Rey C (1995) Originalité du recrutement benthique chez Owenia fusiformis polychaeta: dissémination larvaire et rapport avec le substrat. DEA D'Océanologie biologique, Université Pierre et Marie Curie, Paris

Scheltema RS (1974) Biological interactions determining larval settlement of marine invertebrates. Thalassia Jugoslav 10:263-296

Snelgrove PVR, Butman CA (1994) Animal-sediment relationships revisited: cause versus effect. Oceanogr Mar Biol Annu Rev 32:111-177

Somaschini A (1993) A Mediterranean fine-sand polychaete community and the effect of the tube-dwelling Owenia fusiformis Delle Chiaje on community structure. Int Rev Ges Hydrobiol 78:219-233

Taghon GL, Nowell ARM, Jumars PA (1980) Induction of suspension feeding in spionid polychaetes by high particules fluxes. Science 210:562-564

Thiébaut E, Dauvin JC, Lagadeuc Y (1992) Transport of Owenia fusiformis larvae (Annelida: Polychaeta) in the Bay of Seine. I. Vertical distribution in relation to water column stratification and ontogenic vertical migration. Mar Ecol Prog Ser 80:29-39

Editorial responsibility: John Austin (Assistant Editor), Oldendorf/Luhe, Germany
Thistle D, Reidenauer JA, Findlay RH, Waldo R (1984) An experimental investigation of enhanced harpacticoid (Copepoda) abundances around isolated seagrass shoots. Oecologia 63:295-299

Toulemont A (1972) Influence de la nature granulométrique de sédiments sur les structures benthiques. Baies de Douarnenez et d'Audierne (Ouest-Finistère). Cah Biol Mar 13:91-136

Underwood AJ (1979) The ecology of intertidal gastropods. Adv Mar Biol 16:111-210

Verwey J (1952) On the ecology of distribution of cockle and mussel in the Dutch Wadden Sea. Their role in sedimentation and the source of their food supply. Arch Neerl Zool 10:171-239

Virnstein RW, Mikkelsen PS, Cairns KD, Capone MA (1983) Seagrass beds versus sand bottoms: the trophic importance of their associated benthic invertebrates. Fla Sci 46: $363-381$

Wentworth W (1972) A scale of grade and class terms for clastic sediments. J Geol 30:377-392

Wilson DP (1932) On the mitraria larvae of Owenia fusiformis Delle Chiaje. Philos Trans R Soc Ser B 221:231-334

Wilson DP (1948) The relation of the substratum to the metamorphosis of Ophelia larvae. J Mar Biol Assoc UK 27: 723-760

Wilson DP (1952) The influence of the nature of the substratum on the metamorphosis of the larvae of marine animals, especially the larvae of Ophelia bicornis Savigny. Ann Inst Oceanogr 27:49-156

Wilson DP (1953a) The settlement of Ophelia bicornis Savigny larvae. The 1951 experiments. J Mar Biol Assoc UK 31:413-438

Wilson DP (1953b) The settlement of Ophelia bicornis Savigny larvae. The 1952 experiments. J Mar Biol Assoc UK 32:209-233

Wilson DP (1955) The role of micro-organisms in the settlement of Ophelia bicornis Savigny. J Mar Biol Assoc UK 34: 531-543

Wilson WH Jr (1983) The role of density-dependence in a marine infaunal community. Ecology 64:295-306

Wilson WH Jr (1984) Non-overlapping distributions of spionid polychaetes: the relative importance of habitat and competition. J Exp Mar Biol Ecol 75:119-127

Woodin SA (1978) Refuges, disturbance and community structure: a marine soft-sediments example. Ecology 59: 274-284

Zajac RN (1986) The effects of intra-specific density and food supply on growth and reproduction in an infaunal polychaete Polydora ligni Webster. J Mar Res 44:339-359

Zunarelli-Vandini R, Cognetti-Varriale AM (1978) Distribution des polychètes sur les fonds meubles infralittoraux du Molise (Adriatique). Cah Biol Mar 19:37-45

Submitted: March 12, 1999; Accepted: February 8, 2000

Proofs received from author(s): August 14, 2000 